\title{
Zinc Alloys as Prospective Materials for Biodegradable Medical Devices
}

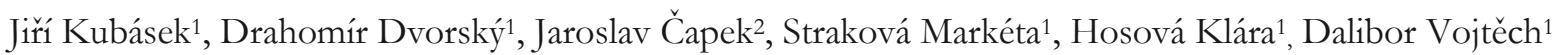
${ }^{1}$ University of Chemistry and Technology Prague, Faculty of Chemical Technology, Department of Metals and Corrosion Engineering, Technická 516628 Praha 6 - Dejvice, Czech Republic., E-mail: kubasekj@vscht.cz ${ }^{2}$ FZU - The Institute of Physics, Czech Academy of Sciences, Na Slovance 1999/2, Prague 8, 182 21, The Czech Republic

Zinc-based materials are considered as promising materials for an application like biodegradable medical devices (bone fixations, stents). Such materials have to be characterized by an excellent combination of mechanical, corrosion and biological properties. Presented paper is focused on the characterization of microstructure and closely related mechanical properties for 3 zinc materials, namely pure $\mathrm{Zn}, \mathrm{Zn}-\mathbf{0 . 8 M g}$ and $\mathrm{Zn}-0.8 \mathrm{Mg}-0.2 \mathrm{Sr}$. Studied alloys were prepared by gravity casting, homogenization treatment at 350 ${ }^{\circ} \mathrm{C}$ and extrusion at $200{ }^{\circ} \mathrm{C}$ and extrusion ratio 11 . Alloying by $\mathrm{Mg}$ caused the refinement of microstructure, formation of $\mathrm{Mg}_{2} \mathrm{Zn}_{11}$ phase and related improvement of mechanical properties like TYS and UTS for an extruded alloy. An additional encore of Sr causes a systematical improvement of TYS and UTS values, although the elongation vas slightly decreased due to the presence of brittle $\mathrm{SrZn}_{13}$ phase.

Keywords: Zinc, magnesium, biodegradable materials, mechanical properties

\section{Introduction}

In the last decade, the development of biodegradable zinc-based materials recorded a significant increase. Such observation is caused by several facts: 1) Zinc is an essential element for the human organism which affect various vital functions and his well acceptable daily dose for an adult is about $20 \mathrm{mg} / \mathrm{day}$, suggesting excellent biocompatibility of this element for the human organism. 2) Zinc is generally characterized by better corrosion resistance compared to the magnesium and its alloys. Besides, the corrosion process is not accompanied by hydrogen release, which causes various complications in the case of biodegradable Mg-based materials. 3) Zinc is less prone to the impurities like in the case of $\mathrm{Mg}$, where element like $\mathrm{Fe}, \mathrm{Cu}, \mathrm{Ni}$, Co cause significant deterioration of corrosion resistance [1-5].

The mechanical properties of pure zinc are poor, therefore improvement by suitable alloying in combination with thermomechanical processing makes sense. In this case, $\mathrm{Mg}$ seems to be a suitable alloying element because it is characterized by excellent biocompatibility and good strengthening effect for $\mathrm{Zn}$ based alloys. Specific concentration equal to $0.8 \mathrm{wt}$. \% has been selected based on the previous experiences and data presented in the literature. Generally, it has been observed that the addition of $\mathrm{Mg}$ to $\mathrm{Zn}$ in the amount higher than 1 wt. \% causes a significant decrease in elongation [4,6-9]. Strontium has been selected as a ternary alloying element due to its good biocompatibility and positive effect on bone resorption
$[2-4,10]$. Since Sr tends to form with $\mathrm{Zn}$ brittle intermetallic phases [10] and the fact that concentrations of $\mathrm{Mg}$ should not be higher than 1 wt. $\%$, we selected appropriate concentration of alloying elements (0.8 wt. $\% \mathrm{Mg}$ and 0.2 wt. $\% \mathrm{Sr}$ ), which sum is equal to 1 wt. $\%$.

Improvement of mechanical properties by alloying is generally insufficient and hot extrusion or hot rolling, which enable materials recrystallization and breakage of intermetallic phases are generally used [1-4]. Therefore, in presented work, the extrusion process in laboratory conditions with an extrusion temperature of $200^{\circ} \mathrm{C}$ and relatively small extrusion ration equal to 11 have been selected to obtain some preliminary results about processing and concomitant behaviour of selected materials.

\section{Materials and methods}

\subsection{Materials}

Pure $\mathrm{Zn}$ was remelted in a graphite crucible in resistance furnace at $550{ }^{\circ} \mathrm{C}$ and cast into the brass mould with $20 \mathrm{~mm}$ in diameter. $\mathrm{Zn}-08 \mathrm{Mg}$ and $\mathrm{Zn}$ $0.8 \mathrm{Mg}-0.2 \mathrm{Sr}$ alloys were prepared from pure metals at the same conditions. The melt was homogenized at $550{ }^{\circ} \mathrm{C}$ for 15 minutes. The as-casted materials were subsequently heat-treated at $350{ }^{\circ} \mathrm{C}$ for 24 hours on air to homogenize the microstructure with subsequent cooling to the water. The billets with $20 \mathrm{~mm}$ in diameter and $20 \mathrm{~mm}$ hight were prepared from as-casted ingots by machining and finally extruded in extrusion die using LabTest 5.250SP1-VM machine at $200{ }^{\circ} \mathrm{C}$ with the ram velocity $5 \mathrm{~mm} / \mathrm{min}$ and extrusion ration 
equal to 11 . The chemical composition of extruded materials is displayed in tab. 1.

Tab. 1 Chemical composition of studied materials.

\begin{tabular}{lccc}
\hline $\begin{array}{l}\text { Material desig- } \\
\text { nation }\end{array}$ & $\begin{array}{c}\mathbf{Z n} \\
{[\mathrm{hm} . \%]}\end{array}$ & $\begin{array}{c}\mathbf{M g} \\
{[\mathbf{h m} . \%]}\end{array}$ & $\begin{array}{c}\text { Sr } \\
{[\mathbf{h m} . \%]}\end{array}$ \\
\hline $\mathbf{Z n}$ & bulk & - & - \\
\hline $\mathbf{Z n - 0 . 8 M g}$ & bulk & 0.76 & - \\
\hline $\mathbf{Z n - 0 . 8 M g - 0 . 2 S r}$ & bulk & 0.80 & 0.17 \\
\hline
\end{tabular}

\subsection{Microstructure}

The microstructure of studied materials was characterised by optical microscopy and scanning electron microscopy (SEM - Tescan VEGA3) equipped with energy dispersion spectrometry (EDS, AZtec). Firstly, samples were ground on SiC grinding papers (P80P2500) and subsequently polished using diamond paste D2 and Eposil M suspension. The grain size was evaluated using image analysis by ImageJ software.

\subsection{Mechanical properties}

Vickers hardness measurement with loading $1 \mathrm{kgf}$ and tensile tests were selected to verify the mechanical properties of studied materials. Tensile tests were performed on "dog bone" specimens with the gauge length of $20 \mathrm{~mm}$ and $4 \mathrm{~mm}$ in diameter on LabTest 5.250SP1-VM at laboratory temperature with the strain rate of $0.001 \mathrm{~s}^{-1}$. Tensile yield strength (TYS) belonging to the $0.2 \%$ proof stress, ultimate tensile strength (UTS), and elongation to fracture (A) were evaluated.

\section{Results and discussion}

\subsection{Microstructure}

The microstructure of studied materials is shown in Fig. 1. As-casted materials are characterized by relatively coarse microstructure. Pure Zn (Fig. 1A) contained large grains with $150-500 \mu \mathrm{m}$ in diameter. The addition of $\mathrm{Mg}$ leads to the refinement of microstructure with dendrite arm spacing (DAS) about $17 \mu \mathrm{m}$. The similar value was observed for $\mathrm{Zn}-0.8 \mathrm{Mg}-0.2 \mathrm{Sr}$ alloy (Fig. 1C). During the solidification of $\mathrm{Zn}-\mathrm{Mg}$ system, intermetallic phases are formed due to the almost neglectable solubility of $\mathrm{Mg}$ in $\mathrm{Zn}$. As a consequence as-cast microstructures of both binary and ternary alloys contained a eutectic mixture of $\mathrm{Zn}$ and thermodynamically stable $\mathrm{Mg}_{2} \mathrm{Zn}_{11}$ phase (Fig. $1 \mathrm{~B}$ and $1 \mathrm{C}$ ) occurring at the interface of dendrites. Besides, $\mathrm{Zn}$ $0.8 \mathrm{Mg}-0.2 \mathrm{Sr}$ alloy contained small particles of $\mathrm{Sr} \mathrm{Zn}_{13}$ intermetallic phase. These particles were arranged inside the eutectic mixture or at their interface with $\mathrm{Zn}$ matrix (Fig. 2A). The reason for such behaviour is related to the solidification of the material. Materials were melted at $550{ }^{\circ} \mathrm{C}$, however, the solubility of $\mathrm{Sr}$ in $\mathrm{Zn}$ is neglectable at this temperature and $\mathrm{Sr} \mathrm{Zn}_{13}$ phase melts even at $830^{\circ} \mathrm{C}$ [11]. After the addition of pure
Sr to the melt, the solid-liquid reaction of $\mathrm{Sr}$ with $\mathrm{Zn}$ take place and solid nuclei of the resulting $\mathrm{Sr} \mathrm{Zn}_{13}$ remains in the melt till the end of solidification which is the formation of the eutectic mixture. Therefore, these phases are enclosed by the eutectic phase. Base on the XRD results (Fig. 3) binary Zn- $0.8 \mathrm{Mg}$ alloys contained also metastable $\mathrm{MgZn_{2 }}$ phase. This phase is occasionally observed in as-casted $\mathrm{Zn}-\mathrm{Mg}$ materials in respect to the cooling rates (12). However, such phase was not observed for $\mathrm{Zn}-08 \mathrm{Mg}-0.2 \mathrm{Sr}$ alloys. It is, therefore, possible, that $\mathrm{Sr}$ affects partially the formation of $\mathrm{Zn}$ $\mathrm{Mg}$ intermetallic phases and support the formation of thermodynamically stable $\mathrm{Mg}_{2} \mathrm{Zn}_{11}$ phase. Due to these differences, $\mathrm{Zn}-0.8 \mathrm{Mg}$ and $\mathrm{Zn}-0.8 \mathrm{Mg}-0.2 \mathrm{Sr}$ alloys were heat-treated at $350^{\circ} \mathrm{C}$ for $24 \mathrm{~h}$ before extrusion to homogenize the microstructure. It is known, that during this annealing, the eutectic phase is replaced by thermomechanically stable $\mathrm{Mg}_{2} \mathrm{Zn}_{11}[12,13]$. If the metastable $\mathrm{MgZn}_{2}$ phase is presented in the microstructure of as-casted material, such phase is also rearranged to $\mathrm{Mg}_{2} \mathrm{Zn}_{11}$. Therefore, the applied thermal treatment ensures a homogeneous and clearly defined state of the microstructure before extrusion.

Extrusion process significantly affects the microstructure of processed materials. During processing, recrystallization causes significant grain refinement for all materials. Finally, pure $\mathrm{Zn}, \mathrm{Zn}-0.8 \mathrm{Mg}$ and $\mathrm{Zn}-$ $0.8 \mathrm{Mg}-0.2 \mathrm{Sr}$ materials are characterized by grain size $15 \pm 6,11 \pm 5$ and $5 \pm 4 \mu \mathrm{m}$, respectively (Fig. 1D,E and F). For both binary and ternary extruded alloys, intermetallic phases are arranged in rows parallel to the extrusion direction (Fig. 1E and F). These phases correspond to the $\mathrm{Mg}_{2} Z_{n_{11}}$. Besides $S r \mathrm{Zn}_{13}$ phase remained enclosed in $\mathrm{Mg}_{2} \mathrm{Zn}_{11}$ or at their interface with Zn matrix (Fig. 2B). The presented phase composition was documented by EDS analysis and confirmed by XRD measurements (Fig. 3). Its worth to mention that Zn-based alloys are generally characterized by specific basal texture with basal planes oriented parallel to the extrusion direction $[2,4,13]$. Although this behaviour was not the subject of the presented research, it is well predictable that such preferred crystallographic orientation will occur in these materials as well.

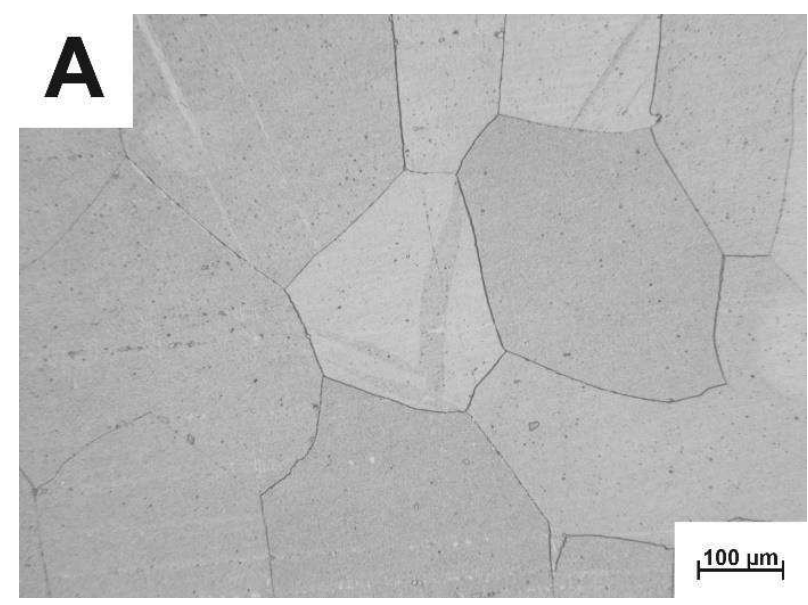



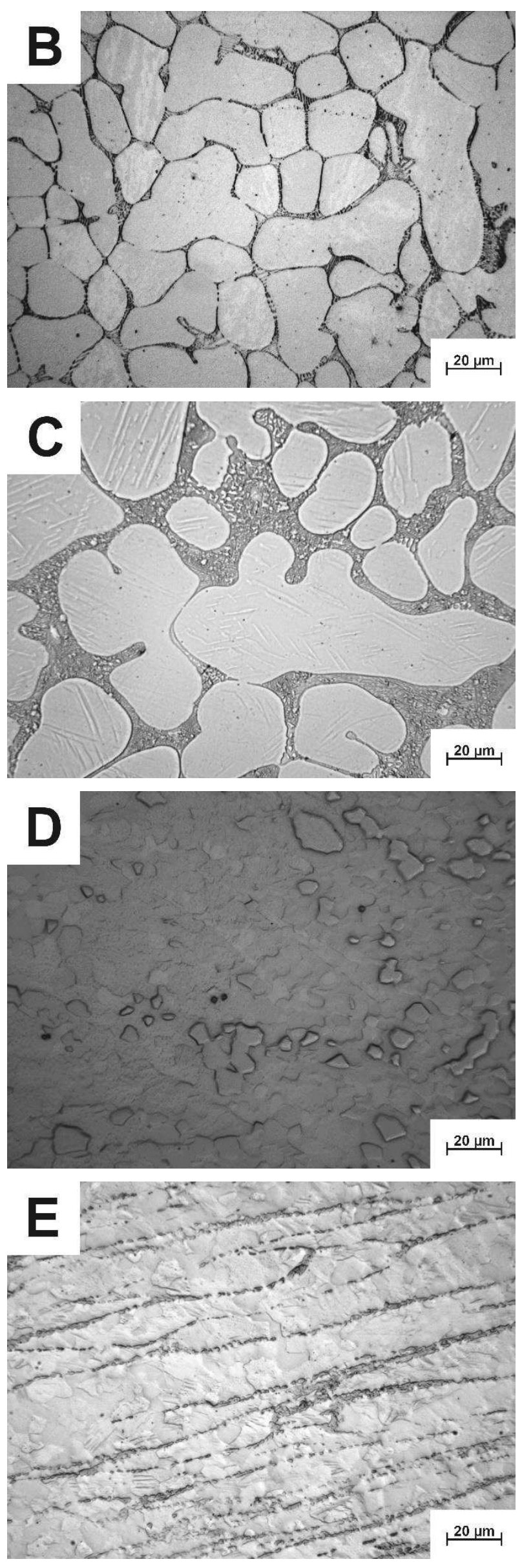

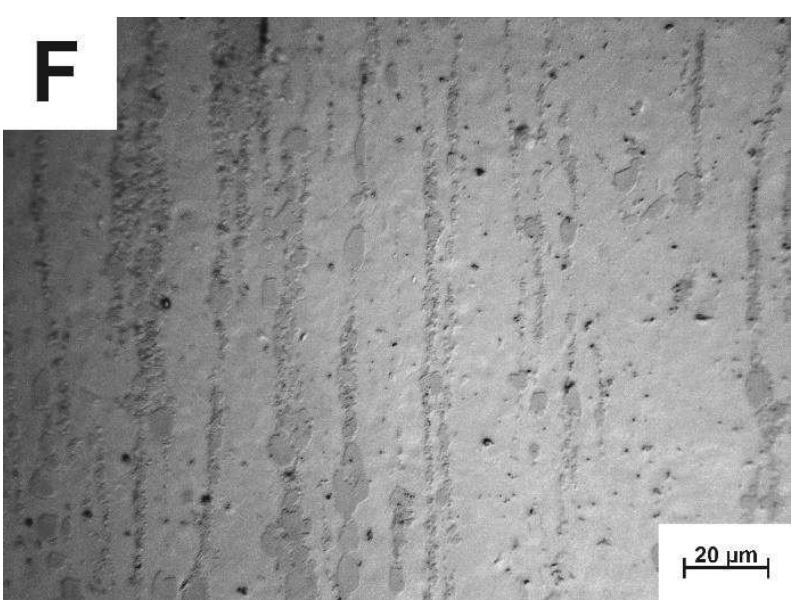

Fig. 1 The microstructure (OM) of: A) as-cast $\mathrm{Zn}, \mathrm{B})$ ascast $\mathrm{Zn}-0.8 \mathrm{Mg}, \mathrm{C})$ as-cast $\mathrm{Zn}-0.8 \mathrm{Mg}-0.25 \mathrm{r}, \mathrm{D})$ as-extruded $Z n$, E) as-extruded $Z n-0.8 M g$, F) as-extruded $Z n-0.8 M g$ $0.2 S r$.
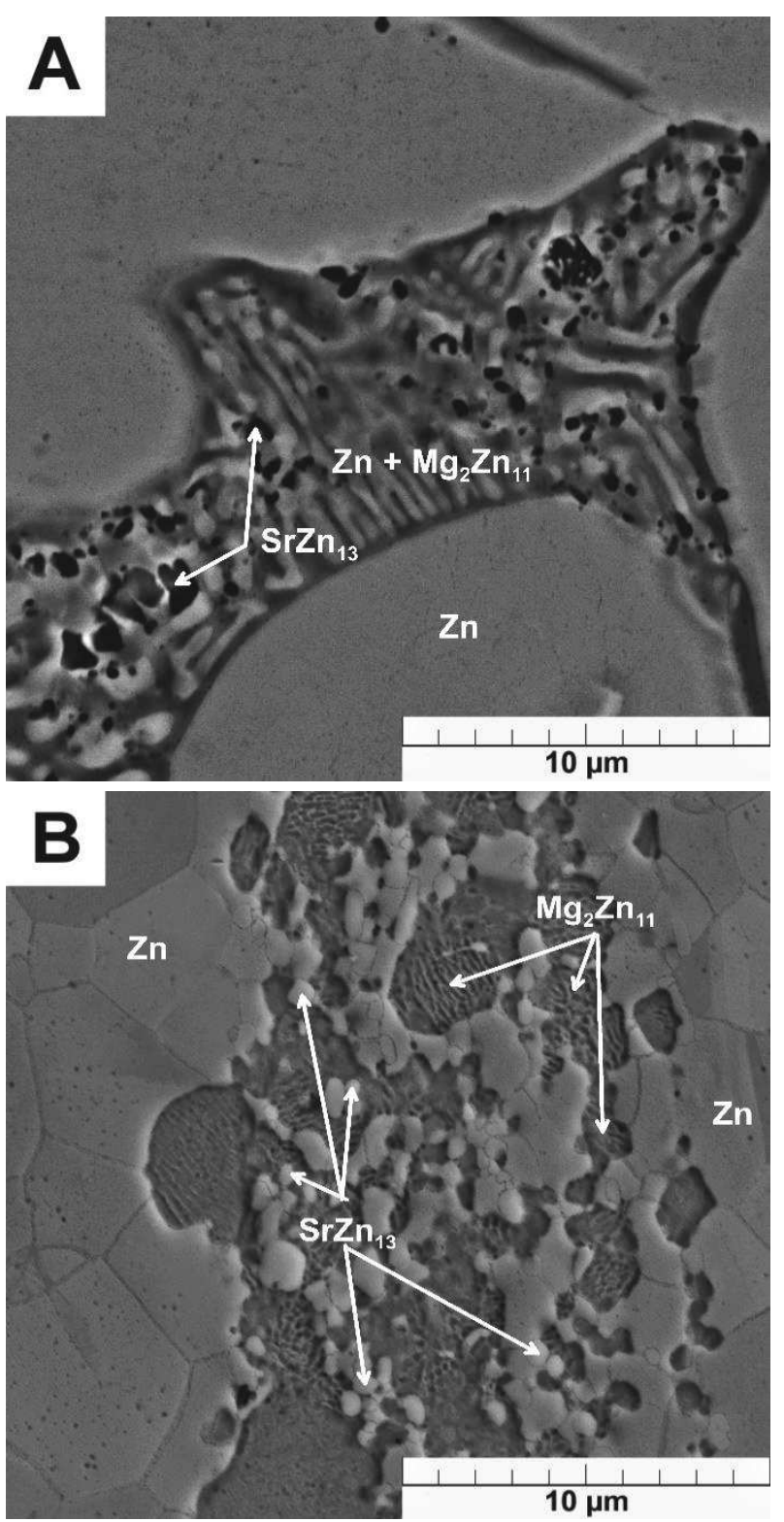

Fig. 2The microstructure (SEM) of: A) as-cast $\mathrm{Zn}-0.8 \mathrm{Mg}$ $0.2 S r, B)$ as-extruded $\mathrm{Zn}-0.8 \mathrm{Mg}-0.2 \mathrm{Sr}$ 


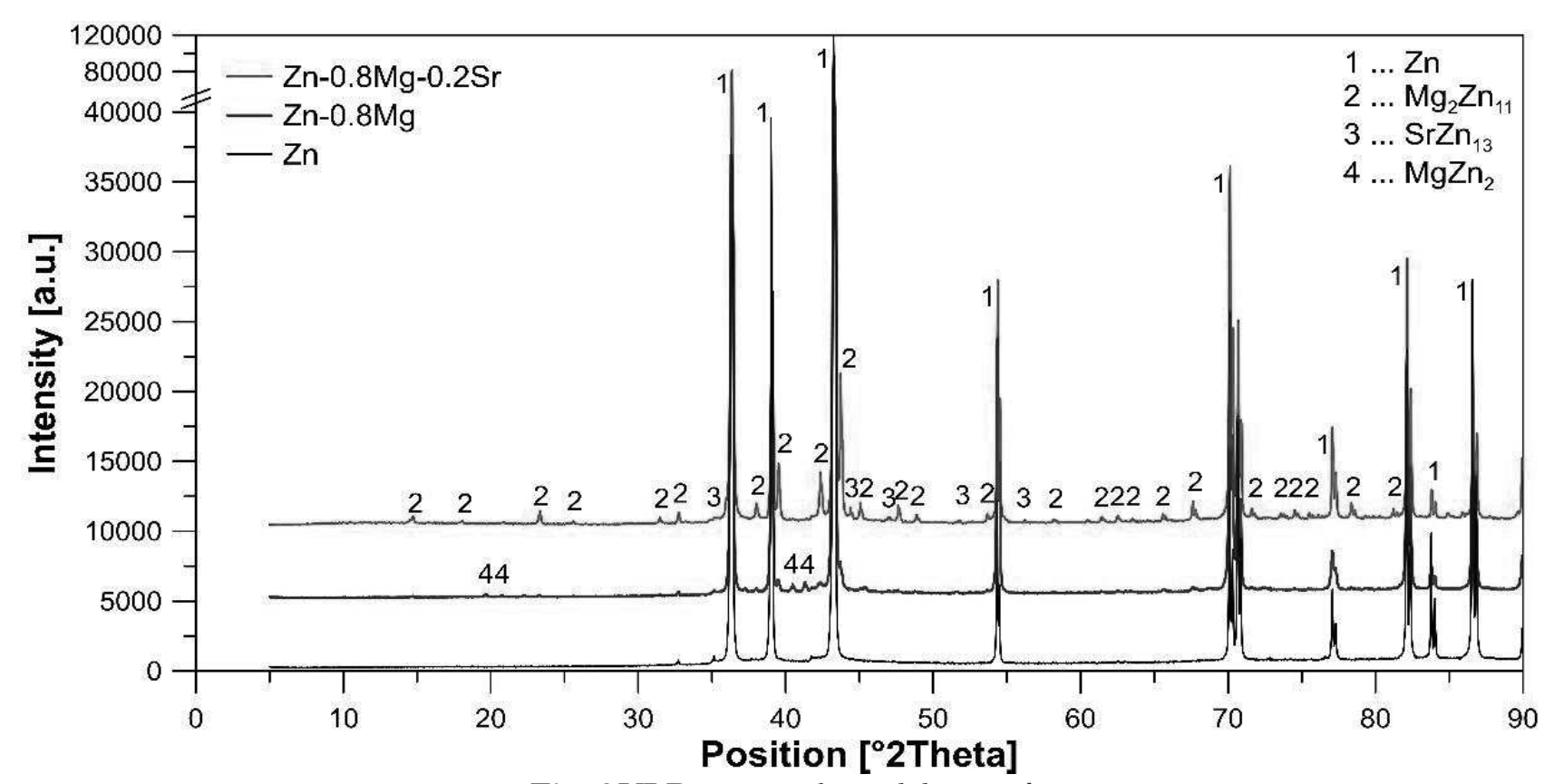

Fig. 3 XRD patterns of extruded materials

\subsection{Mechanical properties}

It is well-known that mechanical properties of the as-cast zinc alloys are characterized by poor mechanical properties, which does not fulfil general requirements for medical devices like traumatological and orthopaedical biodegradable implants. Due to neglectable solubility of $\mathrm{Mg}$ and $\mathrm{Sr}$ in $\mathrm{Zn}$ matrix [11], the improvement of mechanical properties by thermal treatment including artificial ageing is not possible. Therefore, various thermomechanical treatments are generally performed with the greatest use for hot extrusion or rolling. In the presented work, all materials were processed by extrusion at medium temperature $200{ }^{\circ} \mathrm{C}$. Pure $\mathrm{Zn}$ is able to recrystallize at laboratory temperature [4]. Although the recrystallization temperature of alloys may be slightly higher, the selected temperature $200{ }^{\circ} \mathrm{C}$ is sufficiently high for complete recrystallization of studied materials. Significant grain refinement in combination with rearrangement of intermetallic phases to the rows parallel to the extrusion temperature causes significant improvement of mechanical properties as evident in Fig. 3 and Tab. 2. Its worth to mention that tensile properties of extruded $\mathrm{Zn}$ are still very poor with TYS value as low as 43 $\mathrm{MPa}$. However the addition of 0.8 wt. $\%$ of $\mathrm{Mg}$ in combination with extrusion processing lead to the much more promising values of $203 \mathrm{MPa}, 290 \mathrm{MPa}$ and $13 \%$ for TYS, UTS and elongation, respectively. Additional improvement has been observed for ternary $\mathrm{Zn}-0.8 \mathrm{Mg}-0.2 \mathrm{Sr}$ alloys indicating some positive effect of Sr addition on values of TYS and UTS. The difference between $\mathrm{Zn}-0.8 \mathrm{Mg}$ and $\mathrm{Zn}-0.8 \mathrm{Mg}-0.2 \mathrm{Sr}$ materials performance is partially attributed to the decrease in the grain size for ternary alloy and the presence of $\mathrm{SrZn}_{13}$ intermetallic phase. Although, it is also evident that brittle $\mathrm{Sr}_{\mathrm{Zn}} \mathrm{n}_{13}$ cause the gentle decrease of material elongation compared to the binary $\mathrm{Zn}-0.8 \mathrm{Mg}$ alloy. $\mathrm{Zn}-\mathrm{Mg}$ and $\mathrm{Zn}-\mathrm{Mg}-\mathrm{Sr}$ alloys were studied several times $[4,6-10,14]$. Although presented results suggest that both alloys are characterized by acceptable tensile mechanical properties especially owing to mechanical properties observed for Mg-based alloys [1516], TYS, UTS and A values may be still improved by modification of the extrusion process. For example, Capek et.al [13] showed that higher extrusion ratios and lower extrusion temperatures lead to the significant improvement of material elongation. Therefore, modification of these parameters for extruded $\mathrm{Zn}$ $0.8 \mathrm{Mg}-0.2 \mathrm{Sr}$ alloys worth for investigation to process material with a superior combination of strength and plasticity.

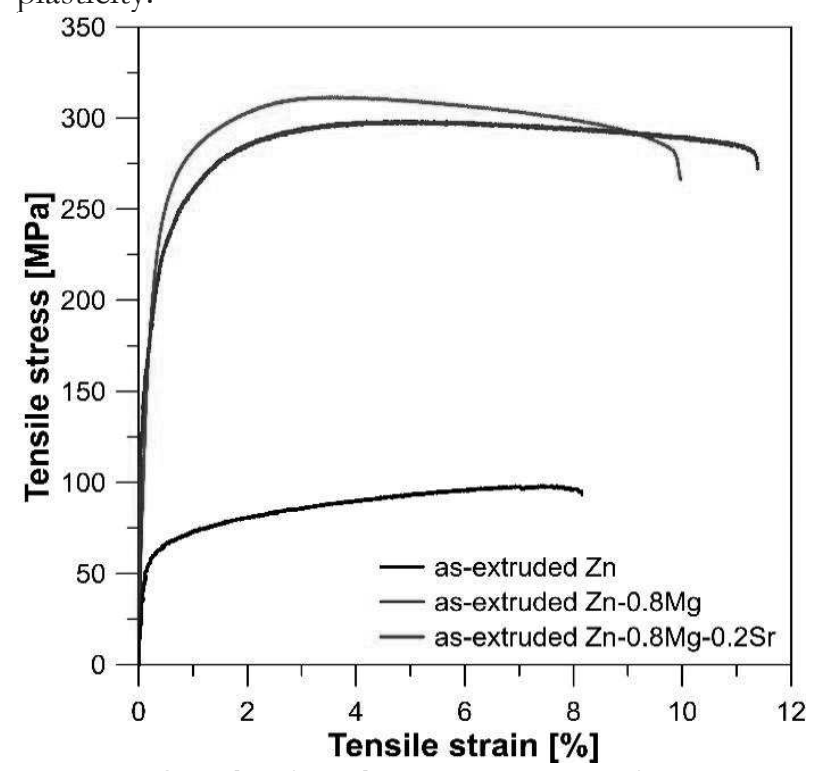

Fig. 3 Samples of tensile stress-strain curves for $Z n, Z n$ $0.8 \mathrm{Mg}$ and $\mathrm{Zn-0.8Mg-0.2Sr}$ in extruded conditions. 
Tab. 2 Mechanical properties of extruded materials

\begin{tabular}{|c|c|c|c|c|}
\hline & $\begin{array}{c}\text { TYS } \\
{[\mathrm{MPa}]}\end{array}$ & $\begin{array}{c}\text { UTS } \\
{[\mathrm{MPa}]}\end{array}$ & A [\%] & HV1 \\
\hline $\mathrm{Zn}$ & $43 \pm 2$ & $89 \pm 4$ & $\begin{array}{c}7.8 \pm \\
0.5\end{array}$ & $\begin{array}{c}41 \pm \\
3\end{array}$ \\
\hline $\mathrm{Zn}-0.8 \mathrm{Mg}$ & $203 \pm 9$ & $290 \pm 11$ & $\begin{array}{c}13.2 \pm \\
1.4\end{array}$ & $\begin{array}{c}82 \pm \\
4\end{array}$ \\
\hline $\begin{array}{l}\mathrm{Zn}-0.8 \mathrm{Mg}- \\
0.2 \mathrm{Sr}\end{array}$ & $243 \pm 7$ & $315 \pm 10$ & $\begin{array}{c}10.1 \pm \\
1.1\end{array}$ & $\begin{array}{c}86 \pm \\
3\end{array}$ \\
\hline
\end{tabular}

\section{Conclusion}

Presented paper deals with the study of free $\mathrm{Zn}$ based materials, namely $\mathrm{Zn}, \mathrm{Zn}-0.8 \mathrm{Mg}$ and $\mathrm{Zn}-0.8 \mathrm{Mg}-$ $0.2 \mathrm{Sr}$. Obtained results indicated that as-cast materials are characterized by coarse-grained structures which is commonly exhibited by worse mechanical properties. Therefore, extrusion has been performed to improve material properties. The microstructure of all extruded materials was characterized by relatively fine recrystallized grains which equivalent diameter $(5-15 \mu \mathrm{m})$ decreased in the order $\mathrm{Zn}>\mathrm{Zn}-0.8 \mathrm{Mg}>\mathrm{Zn}-0.8 \mathrm{Mg}-$ $0.2 \mathrm{Zn}$. Besides, both alloys contained intermetallic $\mathrm{Mg}_{2} \mathrm{Zn}_{11}$ phase accompanied by $S r \mathrm{Zn}_{13}$ in ternary $\mathrm{Zn}$ $0.8 \mathrm{Mg}-0.2 \mathrm{Sr}$. Such microstructure development directly affected the mechanical properties of studied materials. Both extruded alloys were characterized by significantly improved mechanical properties like TYS and UTS compared to the extruded Zn. Addition of Sr has a supplementary positive effect on the increasing value of TYS and UTS compared to the binary $\mathrm{Zn}-0.8 \mathrm{Mg}$, although due to the brittleness of $\mathrm{Sr} \mathrm{Zn}_{13}$ phase, elongation to fracture is slightly decreased for the ternary alloy. Both $\mathrm{Zn}-0.8 \mathrm{Mg}$ and $\mathrm{Zn}-0.8 \mathrm{Mg}-0.2 \mathrm{Sr}$ fulfil the general requirements (TYS $>200 \mathrm{MPa}$, UTS $\approx 300 \mathrm{MPa}$ ) for applications like traumatological and orthopaedic implants.

\section{Acknowledgement}

The authors would like to thank the Czech Science Foundation (project no. 18-06110S) and specific university research A1_FCHT_2020_003 for financial support.

\section{References}

[1] LI, G., YANG, H., ZHENG, Y., et al. (2019). Challenges in the use of zinc and its alloys as biodegradable metals: Perspective from biomechanical compatibility. In: Acta Biomater, Vol. 97, pp. 23-27. Elsevier Sci Ltd. England. ISSN: 17427061

[2] LIU, Y., LU, B., CAI, Z. (2019). Recent Progress on $\mathrm{Mg}$ - And Zn-Based Alloys for Biodegradable Vascular Stent Applications. In: J Nanomater, Vol. 2019, pp. 1-16. Hindawi Ltd. England. ISSN: 16874110
[3] SHUAI, C., LI, S., PENG, S., et al. (2019). Biodegradable metallic bone implants. In: Mater Chem Front, Vol. 3, No. 4, pp. 544-62. Royal Society of Chemistry. England. ISSN: 20521537

[4] VENEZUELA, J., DARGUSCH, MS. (2019). The influence of alloying and fabrication techniques on the mechanical properties, biodegradability and biocompatibility of zinc: A comprehensive review. In: Acta Biomater, Vol. 87, pp. 1-40. Pergamon-Elsevier Science Ltd. England. ISSN: 17427061

[5] SHI, ZZ., GAO, XX., ZHANG, HJ., et al. (2020). Design biodegradable Zn alloys: Second phases and their significant influences on alloy properties. In: Bioact Mater, Vol. 5, No. 2, pp. 210-8. Keai Publishing Ltd. PEOPLES R CHINA. ISSN: 2452199X

[6] KUBASEK, J., VOJTECH, D., JABLONSKA, E., et al. (2016). Structure, mechanical characteristics and in vitro degradation, cytotoxicity, genotoxicity and mutagenicity of novel biodegradable $\mathrm{Zn}-\mathrm{Mg}$ alloys. In: Mater Sci Eng C-Materials Biol Appl, Vol. 58, pp. 24-35. Elsevier Ltd. England. ISSN: 09284931

[7] KUBASEK, J., VOJTECH, D., POSPISILOVA, I., et al. (2016), Microstructure and mechanical properties of the micrograined hypoeutectic $\mathrm{Zn}-\mathrm{Mg}$ alloy. In: Int J Miner Metall Mate, Vol. 23, No. 10, pp. 1167-76. Springer. USA. ISSN: 16744799

[8] KUBASEK, J., POSPISILOVA, I., VOJTECH, D. et al. (2014). Structural, mechanical nad cytotoxicity characterization of as-cast biodegradable $\mathrm{Zn}-\mathrm{xMg}$ ( $\mathrm{x}=0.8-8.3 \%$ ) alloys. In: Mater Tehnol., Vol. 48, No. 5, pp. 6239. Inst za kovinske materiale in technologie. Slovenia. ISSN: 15802949

[9] POSPISILOVA, I., VOJTECH, D., KUBASEK, J. (2014). Structure and properties of zn-mg alloys for medical implants. In: Manuf Technol, Vol. 14, No. 3, pp. 422-7. Univerzita J. E. Purkyne. Czech Republic. ISSN: 12132489

[10] LIU, XW., SUN, JK., QIU, KJ., et al. (2016). Effects of alloying elements ( $\mathrm{Ca}$ and $\mathrm{Sr}$ ) on microstructure, mechanical property and in vitro corrosion behavior of biodegradable $\mathrm{Zn}$ $1.5 \mathrm{Mg}$ alloy. In: J Alloys Compd., Vol. 664, pp. 444-52. Elsevier Science SA. Switzerland. ISSN: 09258388

[11] OKAMOTO H. (2010) Desk Handbook: Phase Diagrams for Binary Alloys, ASM International, ASM Handbooks Series. 
[12] CAPEK, J., KUBASEK, J., PINC, J., et al. (2020). $\mathrm{ZnMg} 0.8 \mathrm{Ca} 0.2$ (wt $\%$ ) biodegradable alloy - The influence of thermal treatment and extrusion on microstructural and mechanical characteristics. In: Mater Charact., Vol. 162, No. 17. Elsevier Science INC. USA. ISSN: 10445803

[13] CAPEK, J., KUBASEK, J., PINC, J., et al. (2020). Extrusion of the biodegradable $\mathrm{ZnMg} 0.8 \mathrm{Ca} 0.2$ alloy - The influence of extrusion parameters on microstructure and mechanical characteristics. In: $J$ Mech Behav Biomed Mater., Vol. 108, No. 16. Elsevier Ltd. England. ISSN: 17516161

[14] VOJTECH, D., KUBASEK, J., SERAK, J., et al. (2011). Mechanical and corrosion properties of newly developed biodegradable Zn-based alloys for bone fixation. In: Acta Biomater, Vol. 7, No. 9, pp. 3515-22. Elsevier Sci Ltd. England. ISSN: 17427061

[15] DVORSKY, D., KUBASEK, J., VOJTECH, D., et. al. (2016). Structure and mechanical properties of WE43 prepared by powder metallurgy route. In: Manuf Technol, Vol. 16, No. 5, pp. 896-902. Univerzita J. E. Purkyne. Czech Republic. ISSN: 12132489

[16] DVORSKY, D., KUBASEK, J., VOJTECH, D., et. al. (2016). Preparation of WE43 using powder metallurgy route. In: ManufTechnol, Vol. 16, No. 4, pp. 680-687. Univerzita J. E. Purkyne. Czech Republic. ISSN: 12132489 